ende grooten van Baros, alle haare vrunden, subjecten ende onderdanen, die nu jongst naar Aetche genavigeert sijn ende haar onder de Aetchinders onthouden, met den eersten over Nijas $\mathrm{p}^{\mathrm{r}}$ de aldaar in negotie leggende Aetchinse vaartuijgen t'huijs te roepen, ende in cas van weijgeringh ende tardance van seven maanden tijts, datse haar voorts ten eeuwigen dagen voor vijanden ende partubateurs van de gemene ruste bij aanhalingh sullen gehouden ende verclaart worden, sonder dat haar in 't minste de naem ende haar geboortplaats van Baros sal comen te verschonen.

Alle welcke bovenstaande gecontracteerde vrede-artijckulen sij, lantsheren en Grooten van Baros, beloven ende sweeren heijliglijk te sullen naarkomen, ende doen naarkomen sonder de minste inbreucke te dulden, ten welcken einde sij, Grooten, dese tot meerder certificatie ende confirmatie hebben onderschreven ende met haare namen geteijckent, gelijk ook bovengenoemde contrahenten uijt den name van den Maninghcabousen coninck ende d'E. Compagnie van haare zijde mede het selve met hare signatuiera ende hantteijcken (op approbatie van haar welgemelte $\mathrm{Ed}^{\mathrm{e}}$ voorn $^{t}$ ) ter ordre van den E. Pits onderteeckent ende met aanroeping van den alderheiligsten name Godts, yder op zijne wijse, geconfirmeert ende bevestight.

Aldus gedaan ende besloten op Baros strant besijden ${ }^{1}$ ) de rivier, ende geschreven in 't jacht Ulpendam, desen 29e April $A^{\circ} 1668$. Was geteeckent Radja 'd'Oulou, ${ }^{2}$ ) Radja d'llheer, orangkaij Balee, Maradja moeda, Radja Sittia Lilla, lantsregeerders op Baros. Hier onder stonden de'eijgen hantteijckeninghs van $\mathrm{d}^{\circ}$ lantsgrooten. Ter zijden stont Joannis Melman als contrahent voor de E. Compagnie, Rene de Radja d'Ilheer van de inlantsche regeringh op Padangh.

\title{
CCCXX. BANDA.
}

16 Mei 1668. $\left.{ }^{4}\right)$

In Juli en Augustus 16655) waren contracten gesloten met eenige der Zuidwester-eilanden. Ofschoon $\mathrm{mij}$ geen voldoende gegevens ten dienste staan om het met zekerheid te zeggen, blijkt : uit het contract zelf wel

1) Besuijden?

2) Hoeloe?

3) Ilir?

4) Uit het Contractboek. In margine staat dáár foutief: "Solor en Timor”.

5) Zię hiẹrvọóo, blḍz. 329 y.v. 
voldoende, dat de gouverneur van Banda Cops van de onveiligheid, aan welke de eilandbewoners bloot stonden door aanvallen van buiten af, gebruik heeft gemaakt, om het Nederlandsche gezag daar op hechter grondslagen te vestigen, vooral tegenover buitenlandsche natiën.

In den jaare naar Cristij geboorte 1668 den $16^{\circ}$ Maij hebben wij ondergeschreven, afgesanten van den E. Heer Jacob Cops, Raat extraordinarij van India, gouverneur en directeur over d'eijlanden Banda etc., met ${ }^{\mathbf{1}}$ ) bevel van hoogh gemelte $\mathrm{E}$. en uijt de naam van den Ed. heer Joan Maatsuijcker, gouverneur generaal over gants Nederlants Orienten van wegen de Honorable ende Uijtlugtige Vereenigde Oostindische Compagnie aen de eene, ende den orangkaij Backer voor hem selven, sijne successeuren en onderdanen aen de ander zijde het verbont van den $11^{\mathrm{e}}$ Julij 1665, tusschen gemelte Compagnie ende hem Orangkaij opgerecht, niet alleen wederzijts vernieut, maar oock noch daar en boven het selve in manieren als volght voor eeuwigh duierent vast gestelt. Te weten :

\section{Articulen.}

Dat hij orangkaij Backer als opperste van de vordere orangkaijs Makisser, hier onder genoempt, oock uijt den naam van haar successeuren en onderdanen, om dat hun selven onmagtich bevinden, hun lant voor enige vijanden te beschermen, uijt eijgen onbedwongen vrije wille ende versoeck en ten principalen tot teecken van danckbaarheijt voor hunne door ons nu verloste ende hun overgeleverde drij hondert ses en twintigh ingeborene sielen, d'welcke enige rovers van Larentouche ${ }^{2}$ ) met hunne konsoorten met gewelt samerhant haar ontrooft en op Letij gevoert hadden, als oock om vordere ontallijcke faveuren ende weldaden by hun van d'E. Compagnie genoten, haar selven verclaren, sweren en belijden, geenen coninck, prins ofte staat subject te sijn, als eenelijck de staght ${ }^{3}$ ) van de Generale Nederlantsche Oostindische Compagnie en in derselver name den E. Heer Gouverneur in Banda, wiens mandaten en beveelen voortaan altoos gehoorsamen en als opregte onderdanen van haar $\mathrm{E}$. sonder eenige contradictie achtervolgen zullen.

2.

Bekennen wij oock dat Haar E. ${ }^{4}$ ) de volkomene superioriteijt ende

1) Uit ?

2) Larantoeka.

3) Staat?

4) De O. I. C. 
eijgendom over onse landen ende volcken uijt regt van onse voorschreven motiven en vrijwillige submissie is competerende.

\section{3.}

Beloven en sweeren wij oock, dat van nu voortaan egene andere potentaten, 't zij Engelse, France, Portugezen, Maccassaren of te eenige andere natien, in hare bevelen sullen gehoorsamen.

\section{4.}

Gelijck wij oock beloven, gene verbonden, contracten en alliantien te sullen aangaan ofte houden met eenige andere Europiaense volckeren, buijten d'E. Compagnie, veel min eenige derselver in onse landen te admitteren, maar bij parresse van grootte magt, die wij niet souden connen wederstaan, aen d'E. Gouverneur voornoemt terstont de wete laaten doen, sonder de minste contradictie.

5.

Sweeren insgelijcx, 't selve in cas van andere Indiaanse natien, namentlijck Maccassaren, Boutonnesen, Javanen, Maleijeren etc. te sullen agtervolgen ende haarlieden de comste aan onse stranden niet alleen met alle mogelijckheijt te weeren; maar oock soo mogelijk d'selve gevangen te nemen ende aan de Compagnie over te leveren, ten ware zij met behoorlijcke paspoorten van de E. Compagnie verscheenen. Ende soo wij des onvermogens zijn te doen, daar van alsvooren datelijck preadvertentie aan den $\mathrm{E}$. heer gouverneur in Banda te laaten toecomen om daar in versien te werden, om alzoo de negotie van dese plaats allenigh aan d'E. Compagnie te verblijven, sonder ijmant meer.

\section{7.}

Dat daarvoor d'E. Compagnie de bescherminge ende heerschappije over haar aenneemt, tegen alle en een ijder, die haar enige schade. ofte leet aandoen willen, gelijck se dan tot dien eijnde met bevel van d'E. Heer gouverneur hier boven genoempt tot hunne bescherminge van nu of aen ter plaetse daer het best geraden zal zijn, sullen opregten een fortie met 2 punten, en 't selve besetten met een sergiant, 2 korporalen, 16 soldaten en 2 bosschieters, oock 't selve met amonitie van oorlog als provisien soodanig versien, datse tot de naaste besending uijt Banda van alles geen gebreck sullen hebben te lijden.

Deze voorenstaande conditien en artijckulen werden wedersijts belooft, [sonder] eenige de minste jnfractie naergecomen en agtervolgt te sullen werden, 't welck naar dat geseijcle organkaij Backer ende 
vordere orangkaijen voor haar, hare successeuren en onderdanen, haaren eedt van getrouwigheijt aan hooggemelte E. Compagnie hebben gedaan, en hun van ons een nieuwe princevlagge vereert zij, en wederzijts met onse gewoonlijcke hantteeckeninge becrachtigt.

Actum in de fluijt Loenen, leggende g'anckert aen de $\mathrm{W}$ : zijde van Makisser, adij $16^{\circ}$ Maij $A^{\circ}$. 1658. Onder stont: dit gemerckt bij orangkaij Backer, gemerkt bij orangkaij Memoetij, gemerckt bij orangkaij Bouron, gemerckt bij orangkaij Leeijrij, gemerckt bij orangkaij Noerij, Marten Roos, gemerckt bij Gillis Leendertse Duijmeijer. Jan Blinne, ${ }^{1}$ ) Christiaen Jurriaenszoon, Abraham Nameur, Alexander Cras, Jan Panne, ${ }^{1}$ ) Davit van Zon en Joris Maes.

\section{SOLOR EN TIMOR.}

\section{Mei-6 Juni $\left.1668 .{ }^{2}\right)$}

In 1655 (zie hiervóór, bldz. 75, v.v.) en 1662 (bldz. 212, v.v.) had de O. I. C. het noodig gevonden, hare betrekkingen met Timor en omliggende eilanden te versterken, waarbij steeds de vrees mêesprak, dat andere natiën (vooral gold dit nog altijd de Portugeezen en hun inlandschen aanhang en de Engelschen) daar invloed kregen of den invloed, dien zij reeds hadden, vermeerderden. (Dagh-Register 1663, bldz. 26, 33, 495 v.v.; 1664, bldz. 33, v., 271 , v., 347 v.; 1665 , bldz. 160, v.). Op een bezending, in 1665 door den luitenant Jacob van de Karper ondernomen "totten handel van sandelhout, wasch etc. nae de Noord-Oostkust van Timor", en later ,nog Oostelijcker op geseijlt nae de plaetsen Ade en Mantoeta ${ }^{3}$ ), bleek, dat deze plaatsen verontrust werden door de Makassaren van den Karaeng van Tello, die rechten op een deel van Timor pretendeerde. (Dagh-Register 1665, bldz. 59) en daarom verzochten hunne radja's ,,seer ernstig, dat de Comp ${ }^{e}$ daer possessie woude comen nemen.... Op Ade leijt een kopermijn van merckelijke considerasie" (bldz. 28z).

I.

Cont en kennelijck zij een ijgelijck dies aangaande, dat wij afgesanten, gesonden uijt den naam van de Heer Jacob Cops, Raet extra-

1) Vg1. bldz. 331 .

2) Uit het Contractboek.

3) Bij Valentijn, IIIb, Solor en Timor, bldz. 121, wordt gesproken van ,het Koningrijk van Ade Mantoetoe”. Het ligt aan de Noord-Oostkust van Timor. thans op Portugeesch gebied. Dagh-Register 1665, bldz. 282 onderscheidt "Ade" en "Mantoete", ieder ondẹr ẹn "radja”. 